\title{
METHODOLOGY
}

\section{Optimization of PCR amplification of maize microsatellite loci*}

\author{
Juliana Bernardi Ogliari', Raquel L. Boscariol ${ }^{2,3}$ and Luis E.A. Camargo ${ }^{3}$
}

\begin{abstract}
Maize (Zea mays L.) microsatellite loci are useful as genetic markers because they are numerous, occur in every chromosome, and have a high content of polymorphism information. Furthermore, they can be amplified by PCR and the resulting fragments resolved on agarose gels. A major problem, however, is that the primers used in their amplification often have different length and nucleic acid content, requiring optimization of PCR amplification programs for each locus. We developed "touchdown" PCR programs successfully used in the amplification of a set of 125-maize microsatellite loci, chosen as representative of all chromosomes. The programs varied both in relation to the annealing temperature (Tm) and primer concentration. Primers could be divided into four groups. A large group included primers that amplified well in a basic previously published amplification program but with different primer concentrations. A second group amplified in alternative programs in which the annealing temperatures were changed so as to include the Tm of either both primers or the highest Tm of the primer pair estimated based on their nucleotide composition. A third group included primers that amplified in programs with Tm higher than those estimated, and in a fourth group, with just two pairs of primers, the opposite situation prevailed.
\end{abstract}

\section{INTRODUCTION}

Variations in DNA sequences have been explored as molecular markers for mapping important genes in plants and animals, during the last two decades. With the advent of the polymerase chain reaction (PCR), new classes of markers emerged that combined the desired characteristics of being highly polymorphic and cost effective, such as RAPD, AFLP, and, more recently, microsatellites. The latter consist of 1 - to 6-bp nucleotide motifs repeated 10 to 50 times in tandem. They can be amplified by PCR, provided the non-repetitive sequences that flank them become known. Microsatellites are present in eukaryotic genomes (Hearne et al., 1992) and were described in various plant species, such as soybeans (Akkaya et al., 1992), Arabidopsis thaliana (Bell and Ecker, 1994), grapes (Browers et al., 1996), sugar beets (Mörchen et al., 1996), rice (Wu and Tanksley, 1993), and tropical trees (Condit and Hubbell, 1991).

Microsatellites abound and are useful as molecular markers in maize because they can be found in all chromosomes and contain a high-polymorphism information content (Senior and Heun, 1993; Chin et al., 1996). Moreover, they are inexpensive and very easy to handle since they require small amounts of template DNA. Finally, information about primers that amplify them either can be found in the Maize Database (http:Ilwww.agron.missouri.edu) or can be bought directly from specialized companies at a low cost. Despite these advantages, there are some practical difficulties. Microsatellite alleles may differ by as few as one base pair, thus requiring samples to be run in high-resolution agarose or polyacrylamide gels. Most importantly, however, is that PCR conditions need to be optimized for each locus, since primers used in their amplification vary both in size and nucleotide composition. To circumvent these problems, Senior et al. (1996) proposed a "touchdown" thermocycling program, where the annealing temperature (Tm) is gradually decreased as the reaction takes place; however, this does not work well for various loci and for this reason other variables, such as primer concentration, must be considered. We developed optimal amplification conditions for a set of 125 microsatellite loci chosen for their ample distribution over all maize chromosomes.

\section{MATERIAL AND METHODS}

PCR optimization was performed using DNA extracted from the maize cultivar $\mathrm{LH} 10 \mathrm{HtHt}$ and the inbred lines L30HtHt, L30Htht, and L30htht, kindly provided by Sementes Agroceres S/A (Uberlândia/MG). The latter three lines, nearly isogenic for a gene that confers resistance against Exserohilum turcicum, were developed by backcrossing using the cultivar as the donor parent. DNA was

*Part of a thesis presented by J.B.O. to the ESALQ/USP in partial fulfillment of the requirements for the PhD degree.

${ }^{1}$ Departamento de Fitotecnia, Centro de Ciências Agrárias, Universidade Federal de Santa Catarina, Caixa Postal 476, 88034-001 Florianópolis, SC, Brasil. Fax: +55-48-334-2014.

${ }^{2}$ Bursar RHAE/CNPq.

${ }^{3}$ Departamento de Entomologia, Fitopatologia e Zoologia Agrícola, ESALQ/USP, Caixa Postal 9,

13418-900 Piracicaba, SP, Brasil. Send correspondence to L.E.A.C.Fax: +55-19-434-4839; E-mail: leacamar@carpa.ciagri.usp.br. 
extracted according to Hoisington et al. (1994) and quantified by fluorometry.

Amplification reactions were done in PTC-100 (MJ Research, USA) thermocyclers in a final reaction volume of $30 \mu \mathrm{l}$ containing $10 \mathrm{ng}$ of DNA template, $0.1 \mathrm{mM}$ of each dNTP, 1 U of Taq DNA polymerase (Promega, USA), $1 \mathrm{X}$ reaction buffer $(50 \mathrm{mM} \mathrm{KCl}, 1.5 \mathrm{mM} \mathrm{MgCl} 2,100 \mathrm{mM}$ Tris- $\mathrm{HCl}, \mathrm{pH} 9$, and $0.1 \%$ Triton $\mathrm{X}-100$ ), additional 0.5 $\mathrm{mM} \mathrm{MgCl}$, and varying concentrations of primers $(0.165$, $0.33,0.5,0.67$ or $1.0 \mu \mathrm{M})$. Amplification reactions were optimized for 125 maize MapPairs ${ }^{\mathrm{TM}}$ primers (Research Genetics, USA), that amplify microsatellite loci from all maize chromosomes. Primer sequences were obtained from the Maize Database (http: Iwww.agron.missouri.edu).

A two-stage touchdown amplification program was designed for each locus based on the Tm of both primers, calculated according to $\mathrm{Tm}=\left[2^{\circ} \mathrm{C}(\mathrm{A}+\mathrm{T})+4^{\circ} \mathrm{C}(\mathrm{C}+\mathrm{G})\right.$ $\left.5^{\circ} \mathrm{C}\right]$ (Newton and Graham, 1997) so that, when possible, both $\mathrm{Tm}$ were included in the program. An initial denaturation step of $3 \mathrm{~min}$ at $94^{\circ} \mathrm{C}$ was used in all programs, followed by a first stage in which the Tm was gradually decreased by $1{ }^{\circ} \mathrm{C}$ following every 2 cycles. This treatment was followed by a second stage consisting of either 19 or 29 amplification cycles, in which the lowest Tm remained constant. Denaturation and elongation steps were held constant for $1 \mathrm{~min}$ at $94^{\circ} \mathrm{C}$ and $2 \mathrm{~min}$ at $72^{\circ} \mathrm{C}$, respectively, during both stages. An elongation step of $6 \mathrm{~min}$ at $72^{\circ} \mathrm{C}$ was performed in all programs after stage 2 (Table I).

Prior to electrophoresis, $3 \mu$ l of loading buffer $(0.25 \%$ bromophenol blue, $0.25 \%$ xylene cyanole, and $30 \%$ glycerol diluted in $\mathrm{H}_{2} \mathrm{O}$ ) was added to the samples. Amplified fragments were resolved in 3\% agarose gels (Boehringer Mannheim $\mathrm{GmbH}$ ) containing ethidium bromide at a concentration of $0.5 \mu \mathrm{g} / \mathrm{ml}$ of gel. Gels were run in $1 \mathrm{X} \mathrm{TBE}$ at $80 \mathrm{~V}$ for $3-5 \mathrm{~h}$ and photographed with Polaroid film.

Table I - Number of cycles and annealing temperatures (Tm) of PCR programs used to amplify maize microsatellite loci. An initial denaturing step was conducted at $94^{\circ} \mathrm{C}$ for 3 min before stage 1 in all programs. In stages 1 and 2, denaturing and elongation conditions were held constant at $94^{\circ} \mathrm{C} / 1 \mathrm{~min}$ and $72^{\circ} \mathrm{C} / 2 \mathrm{~min}$, respectively.

\begin{tabular}{|c|c|c|c|c|c|c|c|c|}
\hline & \multicolumn{8}{|c|}{ PCR Programs } \\
\hline & 1 & 2 & 3 & 4 & 5 & 6 & 7 & 8 \\
\hline & \multicolumn{8}{|c|}{ Stage 1} \\
\hline Cycles & 21 & 11 & 11 & 21 & 11 & 11 & 11 & 11 \\
\hline \multirow[t]{2}{*}{$\operatorname{Tm}\left({ }^{\circ} \mathrm{C}\right)^{\mathrm{a}}$} & $65-55$ & $70-65$ & $65-60$ & $60-50$ & $80-75$ & $60-55$ & $70-75$ & $55-50$ \\
\hline & \multicolumn{8}{|c|}{ Stage 2} \\
\hline Cycles & 19 & 29 & 29 & 19 & 29 & 29 & 29 & 29 \\
\hline $\operatorname{Tm}\left({ }^{\circ} \mathrm{C}\right)$ & 55 & 65 & 60 & 50 & 75 & 55 & 70 & 50 \\
\hline
\end{tabular}

$\mathrm{a}=$ Annealing temperatures were decreased by $1^{\circ} \mathrm{C}$ following every two cycles in all programs.

\section{RESULTS AND DISCUSSION}

Of the 125 primers tested, $63 \%$ successfully amplified microsatellite loci using the PCR program 1 (Table II) described by Senior et al. (1996), even though the predicted Tm of some primer pairs, calculated according to Newton and Graham (1997), were different from the ones used (e.g., bngl109 and phi029).

The remaining 46 primers either did not amplify or did poorly under the conditions of program 1 . For these, alternative programs were tested using the estimated annealing temperatures as a starting point in addition to varying primer concentrations. Thirty-seven pairs of such primers gave good amplification products when used in programs which included annealing temperatures of both primers (18 cases, e.g., bngl652 and bngl609) or just one primer (19 cases, e.g., phi078 and bngl244), often the one with highest $\mathrm{Tm}$. A third group, comprised of seven pairs of primers, showed good amplification products only when amplified in programs with Tm higher than those estimated for either primers (e.g., phi055 and phi094); the opposite situation applied to the remaining two primers bngl653 and phi095 (Table II).

Some primer pairs (bng1603, bngl371, bngl609, bng1244, MAGT01D06, bngl137, bngl279, bngl652, and MACT02E01) revealed multiple bands (stutter bands), irrespective of the program used (not depicted). In these cases, the optimal program was defined as that which resulted in fewer fragments as well as in a strong signal intensity fragment, assumed to be the desired amplicon. Stutter bands result from slippage of DNA polymerase over the template DNA and it is common when the amplicon is comprised of dinucleotide repeats (Brown et al., 1996), as is the case for the primers mentioned above.

A significant improvement of the amplicon quality was seen when the concentration of primers increased using program 1 . However, increased signal strength of the fragment was accompanied by increases of the smear just below it; this could be due to spurious dimeric PCR products resulting from annealing of primers, a common situation in cases where there is a complementary sequence between or within primers at the 3 ' end. This problem was solved by increasing the Tm to 70 to $65^{\circ} \mathrm{C}$ (program 2).

Annealing temperatures estimated on the basis of Newton and Graham's (1997) formula did not always correspond to the best Tm observed, based on the signal strength of the amplicon. This was not unexpected, because the authors had acknowledged that their formula was developed based on hybridization experiments conducted at a higher salt concentration (1 M) and that the resulting Tm might need adjustments for nucleotides longer than $20 \mathrm{bp}$, often the case in microsatellites. Nevertheless, the formula provided a starting point to develop optimized amplification programs for numerous microsatellite loci. 
Table II - PCR programs, primer concentrations and estimated annealing temperatures $\left({ }^{\circ} \mathrm{C}\right.$; between parentheses) of 125 maize microsatellite loci.

\begin{tabular}{|c|c|c|}
\hline $\begin{array}{l}\text { PCR } \\
\text { program }\end{array}$ & Primer [ ] & Microsatellite loci (annealing temperatures) \\
\hline 1 & $0.165 \mu \mathrm{M}$ & 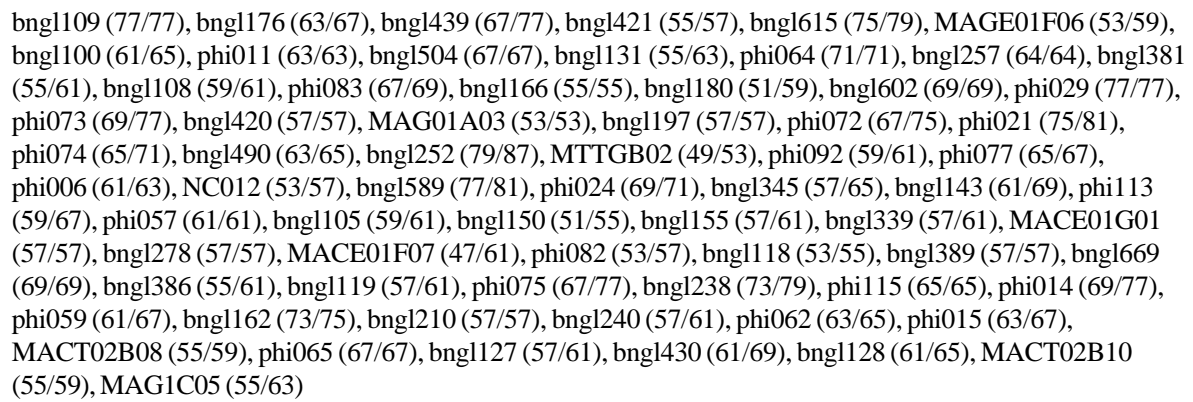 \\
\hline 1 & $0.33 \mu \mathrm{M}$ & $\begin{array}{l}\text { bngl149 (57/65), phi097 (63/67), bngl398 (57/57), bngl434 (55/57), phi063 (55/65), phi071 (65/67), } \\
\text { phi084 (63/67) }\end{array}$ \\
\hline 1 & $0.50 \mu \mathrm{M}$ & bngl125 (57/61), bngl107 (73/77) \\
\hline 1 & $1.00 \mu \mathrm{M}$ & phi034 (61/63) \\
\hline 2 & $0.165 \mu \mathrm{M}$ & phi001 (65/69), phi055 (59/61), phi081 (59/65) \\
\hline 2 & $0.33 \mu \mathrm{M}$ & $\begin{array}{l}\text { bngl652 (67/69), phi094 (59/63), bngl469 (63/65), bngl653 (71/73), phi060 (63/67), phi033 (67/69), } \\
\text { bngl244 (63/69), bngl153 (57/59) }\end{array}$ \\
\hline 2 & $0.50 \mu \mathrm{M}$ & bngl609 (67/69), bngl640 (69/71) \\
\hline 3 & $0.33 \mu \mathrm{M}$ & bng1400 (57/59), bngl371 (55/59), bngl198 (57/65), bngl480 (65/65), bng1572 (59/61), MAGB01 (55/59) \\
\hline 3 & $0.50 \mu \mathrm{M}$ & phi056 (59/63), bngl121 (61/65), phi085 (61/63), phi078 (61/69), phi070 (59/63), bngl236 (65/65) \\
\hline 3 & $1.00 \mu \mathrm{M}$ & MAGT01H07 (57/57) \\
\hline 4 & $0.33 \mu \mathrm{M}$ & MAGE05 (53/59), MACE01A03 (49/50), MACE01C01 (53/57), bng1279 (55/55) \\
\hline 5 & $0.50 \mu \mathrm{M}$ & bng1594 (69/79) \\
\hline 6 & $0.165 \mu \mathrm{M}$ & $\mathrm{NC} 007(53 / 55)$ \\
\hline 6 & $0.33 \mu \mathrm{M}$ & MAG01F03 (55/59), phi008 (55/59) \\
\hline 6 & $0.50 \mu \mathrm{M}$ & $\begin{array}{l}\text { bngl147 (57/79), bngl372 (57/61), bngl292 (57/61), bngl557 (55/61), MACE01C08 (55/55), } \\
\text { bngl137 (55/55), MAG01A01 (53/55) }\end{array}$ \\
\hline 7 & $0.50 \mu \mathrm{M}$ & phi095 (69/77), bng1603 (67/73) \\
\hline 8 & $0.50 \mu \mathrm{M}$ & MACE00B03 (49/53), MACT02E01 (51/61), MAGT01D06 (51/53) \\
\hline
\end{tabular}

See Table I for definition of PCR programs.

\section{ACKNOWLEDGMENTS}

Research supported by FAPESP (grant No. 97/9531-4). Publication supported by FAPESP.

\section{RESUMO}

Locos de microssatélites são úteis como marcadores genéticos pois são numerosos, ocorrem em todos os cromossomos e possuem um alto nível de polimorfismo. Além disso, podem ser amplificados por meio da PCR e resolvidos em géis de agarose. $\mathrm{O}$ maior problema, no entanto, reside no fato de que os primers utilizados em sua amplificação apresentam diferentes comprimentos e composição de nucleotídeos, o que gera a necessidade de otimizar programas de PCR para cada loco. Este trabalho descreve programas de PCR "touchdown" utilizados com sucesso na amplificação de um conjunto de 125 locos de microssatélites de milho escolhidos por serem representativos de todos os cromossomos. Os programas variaram tanto em relação à temperatura de anelamento (Tm), como na concentração dos primers. Assim, os primers puderam ser agrupados em quatro grupos: um grupo maior, constituído por primers que mostraram boa amplificação quando utilizados em um programa básico já publicado porém com concentrações diferentes de primers; um segundo grupo que amplificou em programas alternativos, nos quais as Tm foram modificadas de modo a incluir as Tm de ambos os primers ou a maior Tm do par de primers, estimadas em base da composição nucleotídica dos primers; um terceiro grupo foi composto por primers que amplificaram em programas com Tm mais elevadas que as estimadas, e um quarto grupo, com apenas dois pares de primers, em que a situação oposta ocorreu.

\section{REFERENCES}

Akkaya, M.S., Bhagwat, A.A. and Cregan, P.B. (1992). Length polymorphisms of simple sequence repeat DNA in soybean. Genetics 132: 11311139.

Bell, C.J. and Ecker, J.R. (1994). Assignment of 30 microsatellite loci to the linkage map of Arabidopsis. Genomics 19: 137-144.

Browers, J.E., Dangi, G.S., Vignani, R. and Meredith, C.P. (1996). Isolation and characterization of new polymorphic simple sequence repeat loci in grape (Vitis vinifera L.). Genome 39: 628-633.

Brown, S.M., Szewc-McFadden, A.K. and Kresovich, S. (1996). Development and application of simple sequence repeat (SSR) loci for plant genome analysis. In: Methods of Genome Analysis in Plants (Jauhar, P.P., ed.). CRC Press, Boca Raton, pp. 147-159.

Chin, E.C.L., Senior, M.L., Shu, H. and Smith, J.S.C. (1996). Maize simple repetitive DNA sequences: abundance and allelic variation. Genome 39: 866-873

Condit, R. and Hubbell, S.P. (1991). Abundance and DNA sequence of twobase repeat regions in tropical tree genomes. Genome 34: 66-71.

Hearne, C.M., Ghosh, S. and Todd, J.A. (1992). Microsatellites for linkage analysis of genetic traits. Trends Genet. 8: 288-294. 
Hoisington, D., Khairallah, M. and Gonzälez de León, D. (1994). Laboratory Protocols: CIMMYT Applied Molecular Genetics Laboratory. 2nd edn. CIMMYT, Mexico.

Mörchen, M., Cuguen, J., Michaelis, G., Hänni, C. and Saumitou-Laprade, P. (1996). Abundance and length polymorphism of microsatellite repeats in Beta vulgaris L. Theor. Appl. Genet. 92: 326-333.

Newton, C.A. and Graham, G.A. (1997). PCR. 2nd edn. Springer-Verlag, New York, pp. 192.

Senior, M.L. and Heun, M. (1993). Mapping maize microsatellites and poly- merase chain reaction confirmation of the targeted repeats using a CT primer. Genome 36: 884-889.

Senior, M.L., Chin, E.C.L., Lee, M., Smith, J.S.C. and Stuber, C.W. (1996). Simple sequence repeat markers developed from maize sequences found in the GENBANK Database: map construction. Crop Sci. 36: 1676-1683.

Wu, K.S. and Tanksley, S.D. (1993). Abundance, polymorphism and genetic mapping of microsatellites in rice. Mol. Gen. Genet. 241: 225-235.

(Received September 6, 1999) 